\title{
DNA Restriction and Modification Systems in Salmonella.* SQ, a New System Derived by Recombination Between the SB System of Salmonella typhimurium and the SP System of Salmonella potsdam
}

\author{
By L. R. BULLAS, $\uparrow$ C. COLSON AND ALINE VAN PEL \\ Laboratoire de Cytogénétique, Université de Louvain, \\ Place de la Croix-du-Sud 4, B-I 348 Louvain-la-Neuve, Belgium
}

(Received 25 November 1975; revised I3 February 1976)

\begin{abstract}
SUMMARY
As the result of PI-mediated cotransduction with $\operatorname{ser} B$ from Salmonella potsdam to the Escherichia coli/Salmonella typhimurium hybrid $46 \mathrm{I} 7$, one recombinant, L4004, was isolated which had a restriction-modification $(R-M)$ system different from the SB and SP systems of its parents, and was designated SQ. The genes of SQ were allelic to those of the SB system of $S$. typhimurium and were shown by complementation experiments to be functionally related to those of the $\mathrm{K}$ system of $E$. coli. Evidence that the SQ system in $\mathrm{L} 4004$ arose as the result of a recombination event within the hsdS genes of SB and SP is discussed.
\end{abstract}

\section{INTRODUCTION}

Restriction enzymes are currently classified into two types depending on their properties (for a recent review, see Arber, 1974). Enzymes of type I contain three types of subunits, have complex cofactor requirements and undergo complex interactions with DNA. Most known restriction-modification systems (R-M systems) with type I enzymes are coded by genes on the bacterial chromosome. These genes have the remarkable property of occupying an allelic locus in different bacterial strains. Thus the genes for the Escherichia coli K, B and A systems as well as those of the Salmonella typhimurium SB and Salmonella potsdam SP systems map close to and counter-clockwise to serB (Boyer, 1964; Glover \& Colson, I969; Arber \& Wauters-Willems, I970; Colson \& Van Pel, 1974; Bullas \& Colson, 1975a). In addition, complementation studies in merodiploids have indicated that three of these systems have functional homology - the K, B and SB systems (Arber \& Linn, 1969; Boyer \& Roulland-Dussoix, 1969; Glover, 1970; Van Pel \& Colson, 1974). It is conceivable that these R-M systems were derived from a common ancestor. From the present state of knowledge of restriction enzymes and their genetic determinants, one can suggest that these different $\mathrm{R}-\mathrm{M}$ systems resulted from alterations in the $h s d S$ gene, coding for specific site recognition so that its product then recognized different nucleotide sequences.

The possibility of producing new R-M systems by mutations in $h s d S$ genes or by recombination within $h s d S$ genes has been suggested by Arber \& Linn (1969). However, no new experimentally-produced $\mathbf{R}-\mathbf{M}$ system with an altered specificity has yet been reported.

In a previous paper we demonstrated allelism between the SB system of $S$. typhimurium

* This is paper number IV in the series.

$\uparrow$ Present address: Department of Microbiology, Loma Linda University, Loma Linda, California 92354, U.S.A. 


\title{
Table ${ }_{-}^{-}$. Strains of bacteria
}

Strain

Host specificity phenotype

Genotype*

Reference $\dagger$

Escherichia coli $\mathrm{KI} 2$

$\begin{array}{ll}\mathbf{1} 225 & \mathbf{r}_{\mathbf{K}}^{+} \mathrm{m}_{\mathbf{K}}^{+} \\ \mathbf{1 2 2 8} & \mathrm{r}_{\mathbf{K}}^{\overline{\mathbf{K}}} \mathrm{m}_{\mathbf{K}}^{\overline{\mathbf{K}}} \\ \mathbf{1 2 4 0} & \mathrm{r}_{\mathbf{K}}^{\overline{\mathbf{K}}} \mathrm{m}_{\mathbf{K}}^{+}\end{array}$

\author{
thr leu thi lac \\ thr leu thi lac hsd $S_{K}$ \\ thi $\operatorname{ser} B s t r^{\mathrm{r}} h s d R_{\mathrm{K}}$
}

I
I

Salmonella typhimurium LT2

$4247 \quad r_{\mathrm{LT}}^{+} \mathrm{m}_{\mathrm{LT}}^{+} \mathrm{r}_{\mathrm{SA}}^{+} \mathrm{m}_{\mathrm{SA}}^{+} \mathrm{r}_{\mathrm{SB}}^{+} \mathrm{m}_{\mathrm{SB}}^{+}$

$4419 \quad r_{\mathrm{LT}}^{-} \mathrm{m}_{\mathrm{LT}}^{+} \mathrm{r}_{\mathrm{BA}}^{-} \mathrm{m}_{\mathrm{BA}}^{+} \mathrm{r}_{\mathrm{SB}}^{+} \mathrm{m}_{\mathrm{SB}}^{+}$

$4514 r_{\mathrm{LT}}^{+} \mathrm{m}_{\mathrm{LT}}^{+} \mathrm{r}_{\mathrm{SA}}^{+} \mathrm{m}_{\mathrm{SA}}^{+} \mathrm{r}_{\mathrm{SB}}^{+} \mathrm{m}_{\mathrm{SB}}^{+}$

$4519 \quad r_{\mathrm{LT}}^{+} \mathrm{m}_{\mathrm{LT}}^{+} \mathrm{r}_{\mathrm{SA}}^{+} \mathrm{m}_{\mathrm{SA}}^{+} \mathrm{r}_{\mathrm{SB}}^{+} \mathrm{m}_{\mathrm{SB}}^{+}$

$4532 \quad r_{\mathrm{LT}}^{+} \mathrm{m}_{\mathrm{LT}}^{+} \mathrm{r}_{\mathrm{SA}}^{+} \mathrm{m}_{\mathrm{SA}}^{+} \mathrm{r}_{\mathrm{SB}}^{+} \mathrm{m}_{\mathrm{SB}}^{+}$

$4536 \quad \mathrm{r}_{\mathrm{LT}}^{+} \mathrm{m}_{\mathrm{LT}}^{+} \mathrm{r}_{\mathrm{SA}}^{+} \mathrm{m}_{\mathrm{SA}}^{+} \mathrm{r}_{\mathrm{SB}}^{+} \mathrm{m}_{\mathrm{SB}}^{+}$

met $A$ metB $\operatorname{trp} B$ str $^{\mathrm{r}}$

met $A$ metB $\operatorname{trpB}$ val $s \mathrm{rt}^{\mathrm{r}} h s d R_{L T} h s d R_{S A}$

SerB8o galE 2

serAI3 thr-I7 2

metA metB trpB val pyrBr24 gal

met $A$ metB trpB val serB8o gal 2

Escherichia coli/S. typhimurium hybrid

${ }_{46} \mathrm{I} 7 \mathrm{r}_{\mathrm{SA}}^{+} \mathrm{m}_{\mathrm{SA}}^{+} \mathrm{r}_{\mathrm{SB}}^{+} \mathrm{m}_{\mathrm{SB}}^{+} \quad$ thi lac ${ }_{-}^{-}\left(\operatorname{serB} 80 \text { leu }^{+}\right)^{\mathrm{St}}$

I

Escherichia coli/S. typhimurium/S. potsdam hybrids

\begin{tabular}{|c|c|c|}
\hline L400I & $r_{\overline{S A}}^{-} m_{\overline{S A}}^{-} r_{S B}^{+} m_{S B}^{+}$ & thi lac $\left(l e u^{+}\right)^{\mathrm{St}}\left(\mathrm{serB80^{+ }} h s d_{\mathrm{SA}_{\mathrm{A}}}\right)^{\mathrm{sp}}$ \\
\hline L4002 & $\mathrm{r}_{\overline{\mathrm{SA}}}^{-} \mathrm{m}_{\overline{\mathrm{SA}}}^{-} \mathrm{r}_{\mathrm{SP}}^{+} \mathrm{m}_{\mathrm{SP}}^{+}$ & thi lac $\left(l e u^{+}\right)^{\mathrm{st}}\left(\operatorname{ser} B 80 h s d_{S A}^{-}\right)^{\mathrm{sp}}$ \\
\hline L4003 & $r_{\mathrm{SA}}^{+1} m_{\mathrm{BA}}^{+} r_{\mathrm{SP}}^{+} \mathrm{m}_{\mathrm{SP}}^{+}$ & thi lac $\left(\text {leu }^{+}\right)^{\mathrm{st}}\left(\operatorname{serB80~hsd_{SA}^{-}}\right)^{\mathrm{Sp}}$ \\
\hline
\end{tabular}

Salmonella typhimurium/S. potsdam hybrids

\begin{tabular}{|c|c|c|}
\hline L300I & $\mathrm{r}_{\mathbf{L T}}^{+} \mathrm{m}_{\mathbf{L T}}^{+} \mathrm{r}_{\mathbf{S A}}^{-} \mathrm{m}_{\overline{\mathbf{S A}}}^{-} \mathrm{r}_{\mathrm{SB}}^{+} \mathrm{m}_{\mathrm{SB}}^{+}$ & met $A$ metB $\operatorname{trp} B$ val $\left(p y r B^{+} h s d_{\overrightarrow{S A}}\right)^{\mathrm{Bp}}$ \\
\hline L3002 & $r_{\mathbf{I T}}^{+} \mathrm{m}_{\mathbf{I T}}^{+} \mathrm{r}_{\mathbf{S A}}^{-} \mathrm{m}_{\overline{\mathbf{S A}}}^{-} \mathrm{r}_{\mathbf{S P}}^{+} \mathrm{m}_{\mathbf{S P}}^{+}$ & met $A$ metB trpB val $\left(p y r B^{+} h s d_{S_{A}}^{-}\right)^{\mathrm{sp}}$ \\
\hline 3003 & $r_{I_{T}}^{+} m_{L T}^{+} r_{S A}^{+} m_{S A}^{+} r_{S P}^{+} m_{S P}^{+}$ & metA metB trpB val $\left(p y r B^{+} h s d_{s A}^{-}\right)^{\mathrm{Sp}}$ \\
\hline
\end{tabular}

* Genes outside brackets are from the 'majority parent'; genes inside brackets are from minority parent(s). The superscripts $\mathrm{St}$ and $\mathrm{Sp}$ designate genes from $S$. typhimurium and $S$. potsdam respectively.

$\dagger$ References: I, Colson \& Van Pel (I974); 2, Bullas \& Colson (I975a).

and the SP system of S. potsdam (Bullas \& Colson, 1975a). During the course of these experiments, we found an exceptional recombinant with a new $\mathbf{R}-\mathbf{M}$ system. This paper reports the results of genetic experiments with this recombinant which support the interpretation that it arose as the result of recombination within the $h s d S$ genes of the SB and the SP systems. A preliminary report of our results has already been published (Bullas \& Colson, I975b).

\section{METHODS}

Bacteria and bacteriophages. The various strains of Escherichia coli, Salmonella typhimurium, E. coli/Salmonella and Salmonella/Salmonella hybrids are listed in Table I. Escherichia coli phages $\mathrm{P}_{1}, \mathrm{P}_{2}, 82$ and 434 were from our own collection. Phage $\lambda$, phage $\mathrm{P}_{3}$ which lysed both $E$. coli KI2 and various strains of Salmonella, and $S$. typhimurium phages P22 and L were as used previously (Bullas \& Colson, I975a).

Notations. The notations for host specificity phenotypes and genotypes, and for phage modifications are the same as those used previously (Bullas \& Colson, 1975a) and follow the recommendations of Arber \& Linn (I969) and Arber (I974).

Transductions. Transductions were with phage $\mathrm{PI}$, in the manner previously described (Bullas \& Colson, I975a). 
Table 2. Efficiencies of plating of $P_{3}$ with different modifications on strains with the $S B, S P$ and $S Q$ specificities

\begin{tabular}{lccccc} 
& & \multicolumn{4}{c}{ Efficiency of plating of phage* } \\
Strain & R-M system & $\overbrace{\mathrm{P}_{3} . \mathrm{O}}$ & $\mathrm{P}_{3} . \mathrm{SB}$ & $\mathrm{P}_{3} . \mathrm{SP}$ & $\mathrm{P}_{3} . \mathrm{SQ}$ \\
L4001 & $\mathrm{SB}$ & $\mathrm{I} \cdot 7 \times 10^{-2}$ & 0.79 & $2.5 \times 10^{-2}$ & $2.7 \times 10^{-2}$ \\
L4002 & $\mathrm{SP}$ & $2.5 \times 10^{-3}$ & $4.8 \times 10^{-3}$ & 1.0 & $1.1 \times 10^{-2}$ \\
L4004 & $\mathrm{SQ}$ & $1.9 \times 10^{-2}$ & $8.6 \times 10^{-3}$ & $2.2 \times 10^{-2}$ & 0.34
\end{tabular}

* The efficiencies of plating recorded are relative to that on E. coli $\mathrm{KI} 2$ strain 1228.

Table 3. PI-mediated cotransduction of hsd $d_{s Q}$ with $\operatorname{ser} B$ in E. coli/S. typhimurium hybrid $46 \mathrm{r} 7$

$\begin{array}{lcccccc}\begin{array}{c}\text { Donor } \\ \text { strain }\end{array} & \begin{array}{c}\text { Recipient } \\ \text { strain }\end{array} & h s d_{O} & h s d_{S B}^{+} & h s d_{S Q}^{+} & h s d_{S B}^{+} & \text {Total } \\ \mathrm{L} 4004 & 4617 & 0 & 150 & 102 & 0 & 252\end{array}$

Conjugations. Crosses between S. typhimurium $\mathrm{Hfr}$ and E. coli $\mathrm{F}^{-}$, and characterization of hybrids were done as described by Colson \& Van Pel (1974).

Measure of efficiency of plating of phages. The efficiency of plating (e.o.p.) was indicated by the number of plaques on the test strain relative to the number of plaques on a strain with no detectable $\mathbf{R}-\mathbf{M}$ system. An approximate estimate of the e.o.p. was obtained by spotting known dilutions of phages on the same strains and was adequate, for example, to determine the restriction and modification phenotype of recombinants.

Single-step growth curves. The method of Adams (1959) was followed. Generally, the multiplicity of infection was about $0 \cdot$ or. Samples from the growth tubes were plated out with strain 1228 which possessed zero restriction and modification.

\section{RESULTS}

Isolation of recombinant $\mathrm{L} 4004$ with a new restriction-modification phenotype

By means of PI transduction from $S$. potsdam to the $E$. coli/S. typhimurium hybrid 4617 we have demonstrated that the SB system present in S. typhimurium LT2 is allelic to the SP system in S. potsdam (Bullas \& Colson, 1975a). No recombinants have ever been isolated that possessed both systems. However, from among a total of $230 \mathrm{SerB}^{+}$recombinants that were tested, one recombinant was found which failed to restrict either $\lambda$. SB or $\lambda$. SP. This recombinant was designated $\mathbf{L} 4004$.

Modification tests with phage $\lambda$ indicated that $\mathbf{L} 4004$ failed to modify for either the SB or the SP specificities. This recombinant therefore had the phenotype $r_{\mathrm{sB}}^{-.8} \mathrm{~m}_{\mathrm{sB}}^{-} r_{\mathrm{SP}}^{-} \mathrm{m}_{\mathrm{SP}}^{-}$. Thus L4004, an unusual recombinant which had lost the specificity of one parent without acquiring the specificity of the other, was investigated further.

\section{Efficiency of plating of E. coli phages on $\mathrm{L} 4004$}

The possibility that $\mathbf{L} 4004$ had an $\mathrm{R}-\mathrm{M}$ system but that $\lambda$ had no recognition site for this system was investigated by measuring the e.o.p. of a number of other $E$. coli phages on this recombinant. Phages $\mathrm{P}_{1}, \mathrm{P}_{2}, 82,434$ and $\mathrm{P}_{3}$ were available from our own collection and were therefore used. Results of these tests indicated that phage PI was not restricted by strains with the SB or the SP systems, nor by L4004; phages $\lambda, \mathrm{P}_{2}, 82$ and 434 were each 
Table 4. Efficiencies of plating of phages $P_{22}$ and $L$ with different modifications, on strains of $S$. typhimurium with the $S B, S P$ and $S Q$ restrictions

\begin{tabular}{|c|c|c|c|c|c|c|c|}
\hline \multirow[b]{2}{*}{$\begin{array}{c}\text { Strain } \\
\text { no. }\end{array}$} & \multirow[b]{2}{*}{$\begin{array}{l}\text { Restriction } \\
\text { phenotype }\end{array}$} & \multicolumn{6}{|c|}{ Efficiency of plating of phage* } \\
\hline & & $\begin{array}{c}\text { P22.LT, SA, } \\
\text { SB }\end{array}$ & $\begin{array}{l}\text { P22.LT, SA, } \\
\text { SP }\end{array}$ & $\begin{array}{l}\text { P22. LT,SA, } \\
\text { SQ }\end{array}$ & $\begin{array}{l}\text { L. LT,SA, } \\
\text { SB }\end{array}$ & $\begin{array}{l}\text { L.LT,SA, } \\
\text { SP }\end{array}$ & $\begin{array}{l}\text { L.LT,SA, } \\
\text { SQ }\end{array}$ \\
\hline 4247 & $r_{L T}^{+} r_{S A}^{+} r_{S B}^{+}$ & $I \cdot 0$ & 0.84 & 0.76 & $I \cdot O$ & 0.15 & 0.82 \\
\hline L3003 & $\mathrm{r}_{L T}^{+} \mathrm{r}_{\mathrm{SA}}^{+} \mathrm{r}_{\mathrm{SP}}^{+}$ & $1.8 \times 10^{-3}$ & 1.0 & $2 \cdot 1 \times 10^{-3}$ & $1.4 \times 10^{-3}$ & $1 \cdot 0$ & $2.3 \times 10^{-3}$ \\
\hline L3004 & $r_{\mathbf{L T}}^{+} r_{S \mathbf{A}}^{+} r_{S Q}^{+}$ & $6.7 \times 10^{-4}$ & $3.8 \times 10^{-3}$ & I $\cdot 0$ & $9 \cdot 1 \times 10^{-4}$ & $1 \cdot 4 \times 10^{-3}$ & $I \cdot 0$ \\
\hline
\end{tabular}

* The efficiencies of plating recorded are relative to that on the corresponding propagating strain for each of the phages.

restricted by strains with the SB and the SP systems but were not restricted by L4004; phage $\mathrm{P}_{3}$, on the other hand, was restricted by $\mathrm{L}_{4004}$ as well as by strains with the SB and the SP systems.

A detailed e.o.p. analysis of $\mathrm{P}_{3}$ on strains with the SB and the SP systems as well as on L4004 (Table 2) indicated that $\mathbf{L} 4004$ has an R-M system, which we have called SQ, whose specificity is different from that of either SB or SP.

That the reduced efficiencies of plating of $\mathrm{P}_{3}$ on $\mathrm{L}_{4004}$ shown in Table 2 were due to a restriction-modification mechanism was more directly indicated from the results of a series of single-step growth experiments of $\mathrm{P}_{3}$ with various modifications on $\mathrm{L}_{4}$ 004. $\mathrm{P}_{3}$ propagated on $\mathrm{L}_{4004}$ (i.e. $\mathrm{P}_{3}$.SQ) gave the expected normal growth response, with lysis commencing $50 \mathrm{~min}$ after adsorption at $37^{\circ} \mathrm{C}$ and an average burst size of 47 . On the other hand, no lysis of $\mathrm{L}_{4004}$ occurred with either $\mathrm{P}_{3}$.SB (propagated on strain 4617 ) or $\mathrm{P}_{3} . \mathrm{O}$ (propagated on strain 1228). Only at a high multiplicity of infection of 3 was there lysis with $\mathrm{P}_{3}$.O with an average burst size of only $6 . \mathrm{P}_{3} . \mathrm{O}, \mathrm{SQ}\left(\mathrm{P}_{3} . \mathrm{O}\right.$ propagated on $\left.\mathrm{L}_{4004}\right)$ gave single-step growth parameters that were similar to those obtained with $\mathrm{P}_{3}$. SQ while no lysis of $\mathrm{L}_{4004}$

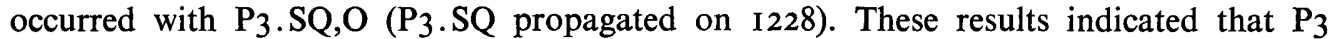
without the SQ modification was restricted by $\mathrm{L} 4004$ and supported the interpretation that the reduced efficiencies of plating of $\mathrm{P}_{3}$ on $\mathrm{L}_{4004}$ were due to a restriction-modification mechanism.

Test for allelism of hsd $d_{s Q}$ to hsd ${ }_{S B}$ in E. coli/S. typhimurium hybrid $46 \mathrm{I} 7$

To map the genes of the new SQ system, a PI lysate was prepared on L4004 and used to transduce $\operatorname{ser}^{+}$to hybrid 4617 . SerB ${ }^{+}$recombinants were examined for their R-M phenotypes. The results are summarized in Table 3. Of $252 \mathrm{SerB}^{+}$recombinants examined, 102 or $40 \%$ inherited the $\mathrm{r}_{\mathrm{SQ}}^{+} \mathrm{m}_{\mathrm{SQ}}^{+}$phenotype. Thus $\mathrm{SQ}$ is controlled by chromosomal genes linked to $\operatorname{ser} B$. Moreover, no recombinant was found that lacked both the SB and the SP restrictions or expressed both restrictions. Thus $h s d_{s Q}$ behaved as an allele of $h s d_{s B}$. This result implies that $h s d_{s Q}$ is also an allele of $h s d_{S P}$ since $h s d_{S P}$ is an allele of $h s d_{s B}$ (Bullas \& Colson, 1975a).

Sensitivity of $S$. typhimurium phages $P 22$ and $L$ to $h s d_{S Q}$

$H s d_{S Q}$ was introduced into $S$. typhimurium strain 4536 by PI $_{\text {I }}$ cotransduction with $\operatorname{ser} B$ from L4004. Of $39 \mathrm{SerB}^{+}$recombinants isolated, four had lost the SBIphenotype and acquired the SQ phenotype as detected with the use of phage $\mathrm{P}_{3}$. In addition, these four $\mathrm{SQ}^{+}$ recombinants restricted both phages $\mathrm{P} 22$ and L. One recombinant was selected and designated L3004. A detailed e.o.p. analysis of the restriction of $\mathrm{P}_{22}$ and L, each with the SB, 
SP and SQ modifications, by $S$. typhimurium strains $4247\left(\mathrm{SB}^{+}\right), \mathrm{L} 3003\left(\mathrm{SP}^{+}\right)$and $\mathrm{L} 3004$ $\left(\mathrm{SQ}^{+}\right.$) was carried out. The results (Table 4 ) show the insensitivity of $\mathrm{P}_{22}$ and L to SB restriction (Colson \& Van Pel, 1974) but clearly show that they are sensitive to SP and SQ restrictions. These results confirm the conclusion previously drawn that L4004 was a recombinant which had acquired a new $\mathbf{R}-\mathbf{M}$ system with a specificity different from that of either of the parental SB or SP systems.

\section{Complementation of an $h s d R_{K}$ mutation by hsd $d_{S Q}$}

To demonstrate further that the SQ system belongs to the series of related systems with type I enzymes, evidence of functional relatedness of SQ with the $\mathrm{K}$ system of $E$. coli was investigated.

An $h s d_{S Q}^{+}$derivative of $S$. typhimurium $\mathrm{HfrK}_{4}$ was first obtained in the following manner. Strain 4519 was made sensitive to phage PI by selecting a rough gal spontaneous mutant (Ornellis \& Stocker, I974; Mojica-a, 1975). This gal strain was made ser $A^{+}$and then ser $B^{-}$ $t h r^{+}$by two successive PI transductions from the $\operatorname{ser} B^{-}$, PI-sensitive strain 45 I 4 . Finally, the $\operatorname{ser} B^{-}$derivative of 4519 was made $h s d_{S Q}^{+}$by $P_{I}$ cotransduction with $\operatorname{ser} B^{+}$from strain L3004.

The $h s d_{S Q}^{+} \mathrm{HfrK}_{4}$ strain was then used as donor in conjugation with $E$. coli strain 1240 , a $\operatorname{ser} B h s d R_{K}$ derivative of $\mathrm{HfrH}$ which had lost donor ability. When used as recipient in crosses with $\mathrm{HfrK}_{4}$, this strain yields an unusually high proportion of those hybrids which are diploid for the $\operatorname{ser} B$ hsd region as a result of the integration of this region of the S. typhimurium chromosome at a non-homologous locus (Colson \& Van Pel, 1974).

Among II such hybrids examined for their restriction capabilities, six showed SA restriction, $S Q$ restriction and $K$ restriction. To confirm that $K$ restriction resulted from complementation of the $h s d R_{K}$ mutation in the recipient chromosome, one of these hybrids was used to transduce $t h r^{+}$to strain I225. Among more than $100 \mathrm{Thr}^{+}$recombinants examined, $30 \%$ had inherited ser $B^{-}$, indicating that the hybrid had retained the recipient $\operatorname{ser} B^{-}$mutation. In addition, $3 \%$ of the $\mathrm{Thr}^{+}$transductants had the $\mathrm{r}_{\mathrm{K}}^{-} \mathrm{m}_{\mathrm{K}}^{+}$phenotype, indicating that the hybrid had retained the $h s d R_{K}$ mutation of the recipient in spite of its $\mathrm{r}_{\mathrm{K}}^{+} \mathrm{m}_{\mathrm{K}}^{+}$phenotype. Since it has been demonstrated that $h s d_{K}$ is not complemented by $h s d_{s A}$ (Van Pel \& Colson, 1974), $\mathrm{K}$ restriction in this hybrid must have occurred as the result of complementation by $h s d_{S Q}$.

\section{DISCUSSION}

Recombinant $\mathrm{L} 4004$ clearly has an R-M system, SQ, which is different from those of its parents. SQ did not originate from an uncontrolled event such as plasmid infection but was the result of a recombination event between $h s d_{S B}$ and $h s d_{S P}$ genes. Its genetic determinants were shown by PI transduction to be chromosomally located and allelic to those of the SB and the SP systems. Moreover, SQ was shown by complementation experiments to be functionally related to the $\mathrm{K}$ system of $E$. coli. Thus SQ is another member of the multiallelic series of related R-M systems in $E$. coli and Salmonella (Bullas \& Colson, 1975a).

The most likely explanation for the origin of SQ is a cross-over within the $h s d_{S B}$ and $h s d_{S P}$ genes. Certainly, other possibilities, such as mutation in genes of the SB or SP systems during the process of recombination repair, cannot be ruled out but would seem to be less probable.

Active sites for SQ were present in the three Salmonella phages, $\mathrm{P}_{3}, \mathrm{P}_{22}$ and $\mathrm{L}$, but were absent from all the $E$. coli phages tested. This ecological distribution of sites is probably without significance however, since $E$. coli phages, particularly phage $\lambda$, possessed both SB 
and SP sites (Colson \& Van Pel, 1974; Bullas \& Colson, 1975a). Moreover, it should be remembered that $\mathrm{L} 4004$ was originally recognized because phage $\lambda$ was unrestricted, i.e. recognition and selection of $\mathrm{L} 4004$ was made with an $E$. coli phage that specifically lacked SQ recognition sites. A survey of other $E$. coli phages, particularly those unrelated to $\lambda$, should certainly reveal some that possess SQ recognition sites.

During a subsequent systematic search for other L4004-like recombinants, only one more $h s d_{s B}^{-} h s d_{s P}^{-}$recombinant was found among $1443 \mathrm{SerB}^{+}$recombinants examined. However, this recombinant was found to be unusual in other respects and its properties will be reported in a separate paper. Thus the overall frequency with which $\mathrm{L} 4004$ was found was no greater than $0.07 \%$. This frequency is at least 0.05 times the frequency at which wild-type $h s d$ recombinants were observed $(\mathrm{I} \cdot 3 \%)$ in similar crosses between mutants in the $h s d R$ and $h s d S$ genes (Bullas \& Colson, 1975a).

Since the genes $h s d R$ and $h s d S$ are closely linked and since the frequency of recombination between mutations in these genes was observed in $\mathrm{I} \cdot 3 \%$ of $\mathrm{SerB}^{+}$recombinants, it is likely that recombinational events within $h s d S$ genes of different specificities $(\mathrm{K}, \mathrm{B}, \mathrm{SB}, \mathrm{SP})$ occur at a higher frequency than that which generated $\mathrm{L} 4004$, but remain undetected because the composite $h s d S$ gene retains the specificity of one of the parents. One might expect that such $h s d S$ genes would code for hybrid polypeptides unable to bind efficiently, or in the right configuration, with the other polypeptides so that no functional enzyme or even inactive enzyme would be formed. The fact that no such recombinant was observed in this work nor in earlier work (e.g., Glover \& Colson, 1969; Bullas \& Colson, 1975a) perhaps indicates that $h s d S$ genes in different systems do not differ sensibly in that part of their sequence which determines the binding properties of the subunit.

This view would imply that $h s d S$ genes for different systems are largely similar and that recombination events leading to a loss of specificity or a change in specificity, as in recombinant L4004, would need to occur in a small restricted region of the gene. This region of the $h s d S$ gene could be that which codes for the active site allowing for the recognition of a nucleotide sequence by that subunit for the type I enzyme which is responsible for the site recognition.

As a result of the isolation of the SQ system in the laboratory and from the fact that multiple, active alleles of the $h s d S$ gene exist in nature, one is led to speculate that this site has an amazing plasticity. Alterations in its amino-acid sequence as a result of recombination or, perhaps, mutation can produce a new active site, specific for another nucleotide sequence.

\section{REFERENCES}

AdAms, M. H. (1959). Bacteriophages, pp. 473-481. New York: Interscience.

ARber, W. (1974). DNA modification and restriction. Progress in Nucleic Acid Research and Molecular Biology 14, I-37.

ARBer, W. \& LinN, S. (1969). DNA modification and restriction. Annual Review of Biochemistry 38, 467-500.

ARBER, W. \& WAUTERS-WILlEMS, D. (1970). Host specificity of DNA produced by Escherichia coli. XII. The two restriction and modification systems of strain I $^{-} \mathrm{T}^{-}$. Molecular and General Genetics 108, $203-217$.

BOYER, H. W. (1964). Genetic control of restriction and modification in Escherichia coli. Journal of Bacteriology 86, $1652-1660$.

BOyER, H. W. \& Roulland-Dussoix, D. (1969). A complementation analysis of the restriction and modification of DNA in Escherichia coli. Journal of Molecular Biology 4I, 459-472.

Bullas, L. R. \& Colson, C. (1975a). DNA restriction and modification systems in Salmonella. III. SP, a Salmonella potsdam system allelic to the SB system in Salmonella typhimurium. Molecular and General Genetics 139, $177-188$.

Bullas, L. R. \& Colson, C. (1975b). SQ, a new restriction-modification system derived by recombination between the SB system in $S$. typhimurium and the SP system in S. potsdam. Genetics 8o, Si 7. 
Colson, C. \& VAN Pel, A. (I974). DNA restriction and modification systems in Salmonella. I. SA and SB, two Salmonella typhimurium systems determined by genes with a chromosomal location comparable to that of the Escherichia coli hsd genes. Molecular and General Genetics 129, 325-337.

GLOVER, S. W. (1970). Functional analysis of host-specificity mutants in Escherichia coli. Genetical Research I5, $448-460$.

Glover, S. W. \& Colson, C. (1969). Genetics of host-controlled restriction and modification in Escherichia coli. Genetical Research $\mathbf{1 3}, 227-240$.

MoJICA-A., T. (1975). Transduction by phage PICM clr-Ioo in Salmonella typhimurium. Molecular and General Genetics $138,113-126$.

Ornellis, E. P. \& Stocker, B. A. D. (1974). Relation of lipopolysaccharide character to PI sensitivity in Salmonella typhimurium. Virology 60, 49I-502.

VAN Pel, A. \& Colson, C. (I974). DNA restriction and modification systems in Salmonella. II. Genetic complementation between the $\mathrm{K}$ and B systems of Escherichia coli and the Salmonella typhimurium system SB, with the same chromosomal location. Molecular and General Genetics 135, 5 I-60. 